\title{
Morbidity and Mortality in Adolescents at the University Hospital of Brazzaville
}

\section{Engoba Moyen ${ }^{1,2^{*}}$, Vérinal Ouemeyi-Enani ${ }^{1}$, Annie Rachelle Okoko1,2, Ben Borgea Nianga ${ }^{3}$, Verlem Bomelefa-Bomel' ${ }^{1}$, Georges Marius Moyen ${ }^{1,2}$}

${ }^{1}$ Faculty of Health Sciences, University Marien Ngouabi, Brazzaville, Congo

${ }^{2}$ Department of Intensive Care Pediatrics, University Hospital of Brazzaville, Brazzaville, Congo

${ }^{3}$ Program and Project Coordination Unit, Ministry of Health and Population, Brazzaville, Congo

Email: *engoba_m@yahoo.fr

How to cite this paper: Moyen, E., Ouemeyi-Enani, V., Okoko, A.R., Nianga, B.B., Bomelefa-Bomel, V. and Moyen, G.M. (2021) Morbidity and Mortality in Adolescents at the University Hospital of Brazzaville. Open Journal of Pediatrics, 11, 243-253. https://doi.org/10.4236/ojped.2021.112024

Received: March 10, 2021

Accepted: June 5, 2021

Published: June 8, 2021

Copyright ( 2021 by author(s) and Scientific Research Publishing Inc. This work is licensed under the Creative Commons Attribution International License (CC BY 4.0).

http://creativecommons.org/licenses/by/4.0/

\section{(c) (i) Open Access}

\begin{abstract}
Introduction: Adolescent morbidity and mortality is a health concern. Objective: To determine morbidity, identify the causes of morbi-mortality and the factors associated with adolescent mortality in Brazzaville. Patients and Methods: A retrospective, descriptive and analytical study was carried out at the Brazzaville Hospital and University Center between January 2015 and December 2016. Adolescents hospitalized in clinical services whose records were workable were included. The Epidemiological, clinical and evolutionary variables were analyzed. The statistical test used was the khi-two, the significance level set at 0.05 . Results: In total, Out of 67,488 hospitalized patients, 2062 were adolescents: $3 \%$ including 891 (43.2\%) boys and $1171(56.8 \%)$ girls mean age $14.8 \pm 2.92$ years, seen in average 9.38 days after the onset of symptoms. Childbirth $415(20.1 \%)$, malaria 309 cases $(14.9 \%)$, major sickle cell crisis $223(10.8 \%)$ and traumatic injuries 166 cases $(8.05 \%)$ are the main causes of morbidity. One death was recorded in $n=193$ (9.4\%), of which $n=104$ (5.0\%) in the first 48 . Tumors, malaria and status epilepticus are the leading causes of death. The female sex, the age between 15 and 19 years, the young age of the father, the higher level of education of the adolescent and the low socio-economic level of the parents are associated with the death. Conclusion: Adolescent morbidity is worrying and mortality is significant. It is important that policies on this issue be developed with an emphasis on the main causes of morbi-mortality, including malaria control and sex education.
\end{abstract}

\section{Keywords}

Adolescents, Morbidity, Mortality, Brazzaville University Hospital 


\section{Introduction}

Adolescence, the period of life from 10 to 19 years, is a journey from childhood to adulthood [1]. It is a period of transition marked by progressive physical, sexual, psychological and social maturation as well as by the acquisition of autonomy. A set of events that make the child an adult [1] [2]. The number of adolescents is estimated at 1.2 billion, or one-fifth of the world's population, four out of five of whom live in developing countries by the World Health Organization (WHO) [1] [3]. About 1.2 million adolescents have died worldwide, two-thirds of them in the regions of Africa and Southeast Asia, making adolescent health a major public health concern [3] [4]. Among the causes of death, road accidents are the first and, the other so-called secondary causes, are attributable to respiratory tract infections, suicide, diarrhoeal diseases and drowning [3]. In developed countries, suicide attempts, traffic accidents, AIDS, and the use of toxics are the main causes of hospitalizations [5]-[11] and road accidents, suicides and cancers are the leading causes of death [12] [13] [14] [15] [16]. In Africa, a continent where adolescent health needs are poorly defined [17], in addition to the causes of the disease, infectious diseases and childbirth are the main causes of morbi-mortality [3] [18] [19] [20] [21]. Also, in order to lay the foundations for a constructive transition to adulthood, various resolutions have been adopted by WHO [22]. And, to guide programmatic actions for adolescent health, the WHO World Assembly has chosen to promote five areas designated "HELPS" [22]. The aim of this study was to contribute to the improvement of adolescent health and to determine the socio-demographic aspects of the adolescent hospitalized at the Brazzaville Hospital and University Centre (CHUB), to identify the causes of morbidity and mortality as well as the factors associated with death.

\section{Patients and Methods}

We reviewed the files of patients hospitalized between January 2015 and December 2016 in the medical and surgical departments of the CHU-B and selected those of adolescents, who constituted the target population of the study. Teenagers whose files were actionable were included. Those whose files were not workable were not included. This was an exhaustive sampling. The study variables were: age, sex, place of residence, provenance, level of education, hospitalization, consultation time, adolescent education level and level of parent education, reason for hospitalization, nutritional status; the cause of hospitalization, length of hospitalization, evolutionary profile and cause of death.

\section{Statistical Analysis}

The data analysis was done using SPSS 20 software. Percentages, averages and standard deviations were calculated. The statistical influence between two variables was assessed by Pearson's khi-two test with a meaning threshold of less than 0.05 .

Confidentiality was respected and a favorable opinion from the ethics committee obtained. 


\section{Results}

\subsection{Descriptive Study}

\subsubsection{Characteristics of the Study Population}

Out of 67488 patients hospitalized during the study period, there were 2062 adolescents: 3\% including 891 (43.2\%) boys and 1171 (56.8\%) girls, i.e. a sex ratio of 0.76 . The mean age was $14.82 \pm 2.92$ extreme years ( 10 and 19 years): it was 14 years for boys versus 15 years for girls. They were between 10 and 14 years old $\mathrm{n}=1162(56.40 \%)$ of which $\mathrm{n}=498(24.2 \%)$ boys and $\mathrm{n}=0.402$ (19.5\%) between the age of 15 and 19 (43.60\%) of which $n=0.393$ (19\%) boys and $\mathrm{n}=769(37.3 \%)$ girls. They came from home without prior recourse to a health center $n=1854$ (89.9\%); from a Level II hospital $n=0.120$ (5.8\%); from a medical practice $\mathrm{n}=27(1.3 \%)$; from a clinic $\mathrm{n}=16(0.8 \%)$ and another locality in Congo $\mathrm{n}=0.45(2.2 \%)$. They were in school $\mathrm{n}=1891(91.7 \%)$ Secondary $\mathrm{n}=$ $1326(64.3 \%)$, Primary $n=562(27.2 \%)$ and at the university $n=3(0.2 \%)$. One hundred and seventy-one adolescents were out of school $n=171(8.3 \%)$. The reception services were pediatrics $n=885(42.9 \%)$, obstetric gynecology $n=448$ $(21.7 \%)$, surgery $n=430(14.5 \%)$ medicine $n=299(14.5 \%)$.

The average consultation time was 9.38 extreme days ( 1 and 180 days). This period ranged from one to two days $\mathrm{n}=1581(70 \%)$, three and seven days $\mathrm{n}=$ $312(15.10 \%)$, seven and 14 days $n=60(2.9 \%)$ and plus 15 days $n=109(5.3 \%)$.

The reason for consultation varied according to the pathology responsible was fever $\mathrm{n}=0.489$ (23.7\%), low-pelvic pain $\mathrm{n}=390(18.9 \%)$, functional impotence $\mathrm{n}$ $=113(5.5 \%)$, convulsive seizure $\mathrm{n}=98(4.98 \%)$, pallor $\mathrm{n}=94(4.6 \%)$, cough $\mathrm{n}=$ $87(4.2 \%)$, consciousness disorder $n=78(3.8 \%)$, vomiting $n=69(3.5 \%)$, abdominal pain $n=67(3.3 \%)$, asthenia $n=47(2.3 \%)$, headache $n=47(2.3 \%)$, genital bleeding $\mathrm{n}=42(2.0 \%)$, otalgia and joint pain $\mathrm{n}=40(1.9 \%)$ everyone, abdominal bloating $n=35(1.7 \%)$, ingestion of toxics $n=35(1.7 \%)$, convulsive disease $n=34(1.7 \%)$, diarrhea $n=28(1.4 \%)$, anemia $n=21(1.6 \%)$, Vulvar discharge $n=16(0.8 \%)$, a burn $n=13(0.6 \%)$, psychomotor agitation $n=9(0.4 \%)$, traumatic wound and hemoptysis $n=7(0.34 \%)$ each, hematuria $n=6(0.29 \%)$, hematemesis, jaundice, coca cola urine and neck pain three cases each $(0.2 \%)$ and a case of epistaxis.

Teenagers were eutrophic $\mathrm{n}=1904$ (92.33\%), emaciated $\mathrm{n}=106(5.14 \%)$, severely emaciated $n=44(2.15 \%)$ and overweight $n=8(0.38 \%)$.

Causes of hospitalization are recorded in Table 1.

\subsubsection{On the Nosological Level}

The Infectious Causes n= 452 (21.9\%) were malaria 309 (68.4\%) of which 152 (49.19\%) simple form and 157 (50.81\%) severe form, tuberculosis $n=38$ (8.4\%), sepsis $n=29(6.4 \%)$, encephalitis $n=12(2.7 \%)$, tetanus, gastroenteritis and meningitis $n=11(2.4 \%)$ each HIV infection $n=9(1.9 \%)$, erysipelas $n=7(1.6 \%)$, meningoencephalitis $n=6(1.3 \%)$. The Other pathologies were measles, hepatitis and chickenpox $n=8(1.8 \%)$ and a case of trypanosomiasis. 
Table 1. Causes of hospitalizations.

\begin{tabular}{ccc}
\hline Causes & \multicolumn{2}{c}{ Cases } \\
\cline { 2 - 3 } Infectious & $\mathbf{N}$ & $\%$ \\
\hline Gyneco-obstetrics & 452 & 21.9 \\
Diseases of the blood and blood-forming organs & 448 & 21.7 \\
Traumatic & 228 & 11.1 \\
Respiratory & 166 & 8.1 \\
Digestive & 138 & 6.7 \\
Uro-nephrologic & 118 & 5.7 \\
Neurologic & 105 & 5.1 \\
Psychiatric & 75 & 3.6 \\
Tumor & 75 & 3.6 \\
ENT & 63 & 3.1 \\
Total & 53 & 2.6 \\
Endocrine, nutritional and metabolic & 51 & 2.5 \\
Osteoarticular & 51 & 2.5 \\
Dermatological & 2062 & 1.0 \\
Cardiovascular & 19 & 0.9 \\
Tor & 200 \\
\hline
\end{tabular}

Gyneco-obstetric causes were: $\mathrm{n}=415$ (92.63\%), vaginal delivery $\mathrm{n}=303$ (73\%) and $\mathrm{n}=114$ (27\%) high-births; hematological causes $\mathrm{n}=228(11.1 \%)$ major sickle cell disease $n=223(97.8 \%)$ and medullary aplasia $n=5(2.19 \%)$; accidental causes $\mathrm{n}=166$, were noted in 112 boys (67.46\%) and 541 girls (32.53 per cent), they were the result of a road accident $n=136$ (81.92 per cent) and sports $\mathrm{n}=30(18.07 \%)$ inducing a fracture $\mathrm{n}=109(65.66 \%)$, a head injury $\mathrm{n}=$ 27 (16.27\%), a burn $n=13(7.83 \%)$ and a wound $n=7$ (4.22\%); osteoarticular causes $\mathrm{n}=51(2.5 \%)$ : arthritis $\mathrm{n}=29(56.86 \%)$ and acute osteomyelitis $\mathrm{n}=22$ (43.13\%); respiratory causes $\mathrm{n}=138(6.7 \%)$ : acute respiratory infection $\mathrm{n}=124$ (89.9\%), asthma exacerbation $\mathrm{n}=13(9.4 \%)$ and a case of respiratory failure; digestive causes $n=118$ (5.7\%): surgical $n=107(90.7 \%) n=11$ (9.3\%); uro-nephrological causes $n=105$ (5.1\%): urinary tract infection $n=53(50.5 \%)$, nephrotic syndrome $\mathrm{n}=15$ (14.3\%), inguino-scrotal hernia $\mathrm{n}=14$ (13.3\%), kidney failure $\mathrm{n}=12$ (11.4\%), hydrocele $\mathrm{n}=7(6.8 \%)$ and acute glomerutolephritis $\mathrm{n}=4(3.8 \%)$; neurological causes $\mathrm{n}=75(3.6 \%)$ : epilepsy $\mathrm{n}=66(88.0 \%)$, cerebral abscess $\mathrm{n}=5$ (6.7\%) stroke $\mathrm{n}=0.4(5.3 \%)$; psychiatric causes $\mathrm{n}=75(3.6 \%)$; tumor causes $\mathrm{n}=$ 63 (3.1\%): nephroblastoma $\mathrm{n}=18(28.6 \%)$, leukemia $\mathrm{n}=10(15.9 \%)$, brain tumors $\mathrm{n}=10(15.9 \%)$, Hodgkin lymphoma $\mathrm{n}=9(14.3 \%)$, retinoblastoma $\mathrm{n}=8$ $(12.7 \%)$, primary liver cancer $n=4(6.3 \%)$, osteosarcoma $n=3(4.7 \%)$ and a case of neuroblastoma; otolaryngological causes $n=53(2.6 \%)$ : acute otitis of otitis $n$ $=-40(75.47 \%)$, mastoiditis $\mathrm{n}=10(18.86 \%)$ and a tympanic perforation $\mathrm{n}=3$ (5.66\%); endocrine, nutritional and metabolic causes $n=51$ (2.5\%); dermatolog- 
ical causes $\mathrm{n}=20(1.0 \%)$ : cellulite $\mathrm{n}=14(70 \%)$, phlegmon $\mathrm{n}=5(25 \%)$ and $\mathrm{a}$ case of Lyell syndrome; cardiovascular causes $n=19$ (0.9\%): heart failure $n=9$ $(47.4 \%)$, pericarditis $n=4(21.1 \%)$, arterial thrombosis $n=3(15.8 \%)$, high blood pressure $n=2(10.5 \%)$ and a case of valvulopathy.

\subsubsection{Evolution}

The average length of hospitalization was 6.96 days, extreme ( 1 and 365 days). The trend was favorable $\mathrm{n}=1881(91.2 \%)$, an exit against medical advice $\mathrm{n}=30$ (1.5\%) and two health transfers. One death was recorded $n=193(9.4 \%)$, of which $\mathrm{n}=104(5.0 \%)$ in the first 48 hours. The main causes of death are recorded in Table 2.

Table 2. Causes of death and case fatality.

\begin{tabular}{|c|c|c|c|}
\hline \multirow{2}{*}{ Causes } & Death & Survival & \multirow{2}{*}{$\begin{array}{c}\text { Lethality } \\
(\%)\end{array}$} \\
\hline & $\mathrm{N}(\%)$ & $\mathrm{N}(\%)$ & \\
\hline Tumor & $27(13.98)$ & 63 & 42.86 \\
\hline Severe malaria & $24(12.43)$ & 157 & 15.28 \\
\hline Epilepsy & $18(9.32)$ & 66 & 27.27 \\
\hline Bacterial lung disease & $11(5.69)$ & 81 & 13.58 \\
\hline Anemia & $6(3.10)$ & 64 & 9.37 \\
\hline Medullary aplasia & $5(2.07)$ & 5 & 100 \\
\hline Encephalitis & $4(2.07)$ & 12 & 33.33 \\
\hline Cerebral abscess & $4(2.07)$ & 5 & 80.00 \\
\hline Nephrotic syndrome & $4(2.07)$ & 15 & 26.66 \\
\hline Tuberculosis & $4(2.07)$ & 38 & 10.52 \\
\hline Sepsis & $3(1.55)$ & 29 & 10.34 \\
\hline Tetanus & $3(1.55)$ & 11 & 27.27 \\
\hline HIV & $3(1.55)$ & 9 & 33.33 \\
\hline Renal faillure & $3(1.55)$ & 12 & 25.00 \\
\hline Lower limb fracture & $2(1.03)$ & 84 & 2.38 \\
\hline Deep vein thrombosis & $2(1.03)$ & 3 & 66.66 \\
\hline Burns & $2(1.03)$ & 13 & 15.38 \\
\hline Heart faillure & $2(1.03)$ & 9 & 22.22 \\
\hline gastrointestinal hemorrhage & $2(1.03)$ & 5 & 40.00 \\
\hline Cholecystitis & $2(1.03)$ & 15 & 13.33 \\
\hline Vaso-occlusive crisis & $2(1.03)$ & 121 & 1.65 \\
\hline Stroke & $2(1.03)$ & 3 & 66.66 \\
\hline Meningitis & $2(1.03)$ & 11 & 18.18 \\
\hline Others* & $56(29.01)$ & 1038 & 5.39 \\
\hline Total & 193 & 1869 & 10.32 \\
\hline
\end{tabular}

${ }^{*} \mathrm{n}=1$. Lyell syndrome, cellulitis, hypertension, appendicitis, peritonitis, intoxication, undernutrition, diabetes, respiratory failure, head trauma, digestive hemorrhage, upper limb fracture. 


\subsection{Analytical Study}

Factors associated with morbidity were the female sex, the 10 - 14 age groups, and the adolescent's secondary education level. Those associated with the risk of death were the female sex, the age between 15 and 19 years, the young age of the father ( $<30$ years), the higher level of education of the adolescent and the low socio-economic level of the parents.

Table 3 shows determinants of adolescent mortality at the CHUB.

Table 3. Shows the determinants of adolescent mortality at the University Hospital of Brazzaville.

\begin{tabular}{|c|c|c|c|c|c|c|c|}
\hline \multirow{4}{*}{ Determinants } & \multicolumn{7}{|c|}{ Clinical evolution } \\
\hline & \multirow{3}{*}{$\begin{array}{c}\text { Total } \\
\mathrm{N}=2062\end{array}$} & \multirow{2}{*}{\multicolumn{2}{|c|}{$\begin{array}{c}\text { healed } \\
\mathrm{N}=1869\end{array}$}} & \multirow{2}{*}{\multicolumn{2}{|c|}{$\begin{array}{c}\text { Death } \\
\mathrm{N}=193\end{array}$}} & \multirow{3}{*}{$\begin{array}{c}\text { OR } \\
\text { (IC à 95\%) }\end{array}$} & \multirow{3}{*}{ p-value } \\
\hline & & & & & & & \\
\hline & & $\mathrm{n}$ & $\%$ & $\mathrm{n}$ & $\%$ & & \\
\hline \multicolumn{8}{|l|}{ Sex (of the adolescent) } \\
\hline male & 891 & 821 & 92.14 & 70 & 7.86 & $1.37[1.01-1.87]$ & 0.04 \\
\hline female & 1171 & 1048 & 89.50 & 123 & 10.50 & 1 & \\
\hline \multicolumn{8}{|c|}{ Age (year-old) of the adolescent } \\
\hline $10-14$ & 1162 & 1097 & 94.41 & 65 & 5.59 & 1 & 0.000 \\
\hline $15-19$ & 900 & 772 & 85.78 & 128 & 14.22 & $2.79[2.04-3.82]$ & \\
\hline Elementary school & 224 & 217 & 96.87 & 7 & 3.13 & $3.49[1.6-7.5]$ & 0.0006 \\
\hline Secondary & 898 & 886 & 98.66 & 12 & 1.34 & $13.50[7.5-24.5]$ & 0.0000 \\
\hline High education & 315 & 245 & 77.77 & 70 & 22.22 & $0.26[0.19-0.36]$ & 0.0000 \\
\hline Unschooled & 625 & 521 & 83.36 & 104 & 16.64 & $0.33[0.24-0.44]$ & 0.0000 \\
\hline \multicolumn{8}{|c|}{ Age (year-old) of mothers } \\
\hline $11-20$ & 224 & 42 & 18.75 & 182 & 81.25 & $0.001[0.0007-0.002]$ & 0.00000 \\
\hline $21-30$ & 896 & 895 & 99.88 & 1 & 0.12 & $17.4[24.6-26.1]$ & 0.000 \\
\hline $31-40$ & 936 & 930 & 99.36 & 6 & 0.64 & 30.8 [13.6 - 69.9] & 0.0000 \\
\hline $41-50$ & 4 & 1 & 25 & 3 & 75 & $0.03[0.003-0.32]$ & 0.0000 \\
\hline 51 and higher & 2 & 1 & 50 & 1 & 50 & $0.10[0.06-1.6]$ & 0.04 \\
\hline Elementary school & 219 & 217 & 99.09 & 2 & 0.91 & $12.5[3.0-50.8]$ & 0.0006 \\
\hline Secondary & 890 & 886 & 99.55 & 4 & 0.45 & $42.5[15.7-115.1]$ & 0.0000 \\
\hline Higher education & 247 & 245 & 99.19 & 2 & 0.81 & $14.4[3.5-58.40]$ & 0.0000 \\
\hline Unschooled & 706 & 521 & 73.80 & 185 & 26.20 & $0.01[0.008-0.03]$ & 0.0000 \\
\hline \multicolumn{8}{|l|}{ Socio-economic level } \\
\hline Low & 1940 & 1755 & 90.46 & 185 & 9.53 & 1 & 0.000 \\
\hline Medium & 118 & 111 & 94.07 & 7 & 5.93 & $135.1[64.9-281.2]$ & \\
\hline High & 4 & 3 & 75 & 1 & 25 & & \\
\hline \multicolumn{8}{|c|}{ Time to admission (days) } \\
\hline $1-7$ & 1893 & 1718 & 90.76 & 15 & 9.24 & 1 & \\
\hline 8 to $\geq 14$ & 169 & 151 & 89.35 & 18 & 10.65 & $1.17[0.7-1.9]$ & 0.54 \\
\hline
\end{tabular}




\section{Discussion}

\subsection{Methodology Analysis}

In order to determine the adolescent's hospital morbidity, identify the causes of hospitalization and deaths, and identify factors associated with adolescent mortality in Brazzaville, we reviewed the hospital records of the CHUB between January 2015 and December 2016. The benefits of this study are the completion of this study in Congo's largest hospital, the sample size and duration. But its retrospective nature is undoubtedly a source of bias.

\subsection{Epidemiological Aspects}

The hospital morbidity of adolescents is $3.4 \%$, frequency close to that reported by Souour in Tunisia 5\% [5]. Higher frequencies are reported by Timité-Konan in Abidjan: 11.3 [21], Djadou: 9.7 [6] and Balaka in Togo [18]: 8.85\%. The study framework and population type explain the disparity in these frequencies. Hospitalized teens have an average age of 14.8 years, those aged 15 to 19 (56.4\%) being most represented, as reported by Djadou [6] where the average age is 13 years and 15 years respectively and the frequency peak between 15 and 19 years (72.8\%) and that of Souour [5], Benallal [23] and Okoko [24] [25] respectively 15.1 years; 14.4 years; 14 years old; 13.5 years and 13.4 years of average age.

A female predominance is reported by some as in our study [6] [16] [19] and male by others [26] [27]. According to African authors, the high number of early pregnancies explains the female predominance, and in developed countries male predominance is due to road-related injuries [28].

The most sought-after services are paediatrics (42.92\%), obstetric gynaecology $(21.73 \%)$ and paediatric surgery $(9.45 \%)$ as Nzamé reports in Gabon [21]. In Ivory Coast [20], the services of gynaecology, paediatric surgery and paediatrics are in descending order and, in Tunisia, the services of paediatrics and hematology [5].

\subsection{Clinical Aspects}

The main morbid entities at University Hospital of Brazzaville are infectious diseases, obstetrical pathologies and childbirth, blood diseases and traumatic injuries. The causes of morbidity vary from one study to another. Timité-Konan [20] notes that infectious diseases are the leading cause of hospitalization among adolescents aged 10 to 14 and deliveries and postpartum infections in those aged 15 to 19 . This is also the case with the prevalence of infectious diseases and deliveries for Djadou [6]. Gynecological-obstetric and infectious pathologies for Nzame [22] and Balaka [18] and diseases of the genitourinary, endocrine, nutritional and infectious diseases for Souour [5].

In terms of infectious diseases, malaria is the leading cause of adolescent morbidity and mortality in Brazzaville and Abidjan [6] [29] [30] [31]. However, this is not the case in Lomé [18] and Libreville [20] where malaria is the second leading cause of hospitalizations for adolescents, which are the second leading 
cause of obstetric gynaecology-obstetric pathologies [18] [20].

In terms of gynaecological and obstetrics, our study confirms African data that, childbirth is the leading cause of adolescent hospitalization in obstetric gynecology services [8] [20] [21]. The precocity of sexual intercourse, the lack of sex education and the lack of knowledge of contraceptive methods for some [32] and the low purchasing power of parents, the source of the girl's out-of-school education for others [6] are the source of the precocity of unwanted pregnancies.

Traumatic pathology is dominated by fractures, contusions, bruises and wounds, the main causes of hospitalizations of adolescents in surgical services [6] [20] [27]. These injuries are readily caused by a road accident and more in male adolescents due to hyperactivity [6] [20] [26] [27].

The frequency of voluntary poisoning, mental disorders and behaviour is higher in this study compared to the studies of the authors consulted [33] [34]. Beyond the difference in frequency, adolescence, a period characterized by an impulse irruption with an easy passage to action and a tendency to impulsiveness explains why attempts to suicides are more common. But their psychological vulnerability is largely related to environmental attitudes and reactions [25].

\subsection{Evolution}

A death was recorded in $9.4 \%$ of cases, of which $5.0 \%$ were reported in the first 48 hours in Brazzaville. In developing countries, as reported in Ghana and Togo, adolescents pay heavy prices for the disease, although at varying rates [18] [19] [21] [35] [36]. It was noted a relationship between the female sex, the age group of 10 to 14 years and the secondary education level of the adolescent and morbidity. And between the female sex, the age between 15 and 19 years, the young age of the father, the higher level of education of the adolescent and the low socio-economic level of the parents and mortality.

\section{Conclusion}

The adolescent hospitalized at the Brazzaville Hospital and University Center has high morbidity and mortality. The main morbid entities are infectious and parasitic diseases, pregnancies, sickle cell disease and traumatic injuries. And, tumors and infectious diseases including severe malaria, the main causes of death. The female sex, the high age of adolescents, the young age of the father, the adolescent's higher level of education and the low socio-economic level of the parents are associated with death.

\section{Conflicts of Interest}

The authors declare no conflicts of interest regarding the publication of this paper.

\section{References}

[1] World Health Organization (2002) Services de santé adaptés aux adolescents: Un 
programme pour le changement [enligne].

http://www.who.int/child_adolescent_health

[2] Desandes, E. (2013) Epidémiologie des cancers de l'adolescent. Revue d'oncologie pédiatrique, 1, 15-20. https://doi.org/10.1016/j.oncohp.2013.04.002

[3] World Health Organization (2016) Adolescents: risques sanitaires et solutions. Aide-mémoire[en ligne]. Mai 2016, No. 345. http://www.who.int/mediacentre/factsheets/fs345/fr/

[4] World Health Organization (2001) Santé de Padolescent. Stratégie de la région Africaine. AFR/RC51/10 Rev.1.28 juin 2001

[5] Souour, Y., Jdidi, J., Abderraouf, K., Habid, F., Mondher, K. and Damak, J. (2010) Adolescent's Hospital Morbidity in Sfax-Tunisia. La tunisie Médicale, 88, 399-403.

[6] Djadou, K., Kanassoua, K., Douti, K., Sededji, A. and Atakouma, D. and Agbere, A. (2010) Morbidité et mortalité des adolescents à l'hôpital de Tsévié (Togo). Journal de Pédiatrie et de Puériculture, 23, 191-197.

https://doi.org/10.1016/j.jpp.2010.04.004

[7] Inserm, S.C. (1995) Repères épidémiologiques. Actualité et dossier en santé publique, 10, 4-9.

[8] Chiolero, A. and Schmid, H. (2000) Morbidité accidentelle à l'adolescence: Une étude représentative auprès des écoliers de 12 à 15 ans en suisse. Swiss Medical Weekly, 130, 1285-1290.

[9] Wayne Sells, C. and Wm, R. (1996) Morbidity and Mortality among US Adolescents: An Overview of Data and Trends. American Journal of Public Heath, 86, 513-519. https://doi.org/10.2105/AJPH.86.4.513

[10] Giraud, P., Fortanier, C., Fabre, G., Ghariani, J., Guillermain, Y., Rouviere, N., et al. (2013) Tentatives de suicide: étude descriptive d'une cohorte de 517 adolescents de moins de 15 ans et 3mois. Archives de Pédiatrie, 20, 608-615.

https://doi.org/10.1016/j.arcped.2013.03.024

[11] Suraya, A.M., Fam, M., Azzopardi, P., Epi, M., Patton, C., Mokdad, A., et al. (2017) Child and Adolescent Mortality Across Malaysia's Epidemiological Transition: A Systematic Analysis of Global Burden of Disease Data. Journal of Adolescent Health, 61, 424-433. https://doi.org/10.1016/j.jadohealth.2017.05.014

[12] Sai, Y., Desmeuls, M., Howard, M., Semenciw, R., Ugnat, A.M., et al. (2007) Adolescent Injury Deaths and Hospitalization in Canada: Magnitude and Temporal Trends (1979-2003). Journal of Adolescent Heath, 41, 84-92. https://doi.org/10.1016/j.jadohealth.2007.02.011

[13] Gréze, V., Chambon, F., Isfan, F., Pereira, B. and Kanold, J. (2015) Epidémiologie et Parcours de soins des adolescents de 15 à 19 ans atteints de cancers diagnostiques en Auvergne entre 2008 et 2013. Revue doncologie hématologie Pédiatrique, 3, 125-133. https://doi.org/10.1016/j.oncohp.2015.06.004

[14] Stheneur, C. (2006) Tentative de suicide: Comment repérer un adolescent en danger. Journal de Pédiatrie et de Puériculture, 19, 218-222. https://doi.org/10.1016/j.jpp.2006.06.004

[15] Walburg, V., Zakari, S. and Charol, H. (2014) Rôle du buront scolaire dans les idées de suicide des adolescents. Neuropsychiatrie de Penfance et de Padolescence, 62, 28-32. https://doi.org/10.1016/j.neurenf.2013.08.002

[16] Grandclerc, S., Moro, M. and Lachal, J. (2017) Etude des spécificités de l'expérience Automutilatrice et suicidaire chez des adolescentes en milieu transculture. Neuropsychiatrique de $\mathrm{P}$ enfance et de $\mathrm{P}$ adolescence, 65, 245-256. 
https://doi.org/10.1016/j.neurenf.2016.11.004

[17] Sawadogo, N., Garanet, F., Traoré, D., Somé/Béré, C., Maré, Z. and Dabiré, G. (2018) Morbidité des adolescents au centre hospitalier régional de kaya (Burkina Faso). Mali médical 2018 TOME XXXIII No. 1.

[18] Balaka, B., Dassas, K., Agbeko, E., Douti, K., Agbere, A. and Kessie, K. (2010) Morbidité et mortalité hospitalière des adolescents: Quelle médecine de l'adolescent en pays africain? Revue maghrébine de pédiatrie, 20, 247-255.

[19] Djadou, K., Koffi, K., Kanassoua, K., Guedenon, K., Adjogan, K.M., Tatagan-Agbi, K., et al. (2011) Morbi-mortalité des adolescents à la pédiatrie du CHR-Tsévié en 2009. Journal de la Recherche Scientifique de l'Université de Lomé, 13, 18-25.

[20] Timité-Konan, A., Akaffou, A., Adonis-Koffy, L., Yapo, M. and Weffen, E. (2003) Morbidité hospitalière de l'adolescent à Abidjan. Médecine d'Afrique Noire, 50, 163-168.

[21] Vierin, N., Mbadinga, B.B.U., M'asseko, M., Mikala, H., Ategbo, S., et al. (2015) Morbidité hospitalière de l'adolescent à Kanda. Archives de Pédiatrie, 22, 233-371.

[22] World Health Organization (2015) Santé des adolescents: Rapport du secrétariat[en ligne]. Avril 2015, A68/15. http://www.who.int/adolescent/second-decade

[23] Benallal, K., Talbi, N., Bentaallah, A., Djeloul Daouedji, Y. and Benaissa, S. (2015) Tentative d'autolyse par ingestion de produits toxiques en pédiatrie en Algérie. Archives de Pédiatrie, 22, 277. https://doi.org/10.1016/S0929-693X(15)30359-6

[24] Okoko, A., Ekouya-Bowassa, G., Moyen, E. and Moyen, G. (2017) Tuberculose chez l'adolescent à Brazzaville. Archives de Pédiatrie, 24, 590-591.

https://doi.org/10.1016/j.arcped.2017.03.003

[25] Okoko, A., Ekouya-Bowassa, G., Oko, A., Mbika-Cadorelle, A., Dzalamou, M. and Moyen, G. (2011) Tentatives de suicide de l'enfant et de l'adolescent à Brazzaville. Archives de Pédiatrie, 18, 809-811. https://doi.org/10.1016/j.arcped.2011.04.018

[26] Thébot, B. (2008) Epidémiologie des accidents chez les enfants et adolescents. Archives de Pédiatrie, 15, 58-60. https://doi.org/10.1016/S0929-693X(08)71901-8

[27] Velin, P., Alamir, H., Babe, P., Guida, A., Four, R., Montaz-Rosset, et al. (2001) Les adolescents aux urgences de l'hôpital Lenval pour enfants à Nice en 1999. Archives de Pédiatrie, 8, 361-367. https://doi.org/10.1016/S0929-693X(00)00211-6

[28] Ekoule Mbaki, H.B., Moyen, E., Mieret, J.C., Ngakosso, O.B. and Moyen, G.M. (2018) Traumatismes Craniens de l'Enfant: Aspects Epidemiologiques et Preise en Charge au Centre Hospitalier Universitaire de Brazzaville. Health Sciences and Disease, 19, 123-126.

[29] Okoko, A., Angouma Oya, S., Moyen, E., Kambourou, J., Ekouya-Bowassa, G., Atanda, H. and Moyen, G. (2016) Paludisme grave de l'enfant au centre Hospitalier et Universitaire de Brazzaville. Journal de Pédiatrie et de Puériculture, 29, 304-309. https://doi.org/10.1016/j.jpp.2016.09.004

[30] Okoko, A., Galiba, F., Oko, A., Moyen-Engoba and Moyen, G. (2008) Activité transfusionnelle pédiatrie au CHU de Brazzaville. Revue Cames. Série A, 6, 30-33.

[31] Moyen, A., Mbika, C., Kambourou, J., Oko, A., Mouko, A. and Obengui (2010) Paludisme grave de l'enfant à Brazzaville. Médecine d'Afrique Noire, 57, 113-116.

[32] Guttmacher Institute (2020) Les faits sur la santé sexuelle et reproductive des adolescentes dans le monde en developpement.

[33] De Tournemire, R. (2010) Suicides et tentatives de suicide à l'adolescence "Données épidémiologiques: Comment s’y retourner?” Archives de Pédiatrie, 17, 1202-1209. https://doi.org/10.1016/j.arcped.2010.05.011 
[34] Caflish, M. and Alvin, P. (2000) La prise en charge des adolescents en pédiatrie hospitalière. Une enquête nationale. Archives de Pédiatrie, 7, 732-737.

https://doi.org/10.1016/S0929-693X(00)80153-0

[35] Ohene, S.A., Tettey, Y. and Kumoji, R. (2011) Cause of Death among Ghanaian Adolescents in Accra Using Autopsy Data. BMC Research Notes, 4, Article No. 353. https://doi.org/10.1186/1756-0500-4-353

[36] Ajij, M. and Pembe, H.K. (2015) 94. Adolescent Mortality Patter in Tertiary Level Teaching Hospital in North India. Journal of Adolescent Health, 56, S49-S50. https://doi.org/10.1016/j.jadohealth.2014.10.100 